DE DE GRUYTER

OPEN

DOI: 10.1515/aa-2015-0005

\title{
The elements of humanity and Sufism in Henry David Thoreau's Walden
}

\section{Ali Arian}

Ali Arian has worked as a faculty member of English Language and Literature Department, Azarbaijan Shahid Madani University, Tabriz-Iran. His field of specialization is literature in English, with a particular interest in the works of American $19^{\text {th }}$ century writing, including the literary oeuvre of Henry David Thoreau.

\begin{abstract}
It seems that the very important role of literature is its transcendental appeal. Literature knows no boundary and it ties whole nations even if they are politically segregated. The present paper tries to trace some of the salient features of humanism and Sufism, such as Absolute Unity, simplicity, selfknowing, purity, solitude, loving one another and some others in Henry David Thoreau's Walden. This American writer, as an ardent follower of the Transcendental Club in America and the holy scriptures of the East, was known as the hero of simplicity in the U.S.A. Being a protester against government and society, he dwelled for more than two years alone in Walden Pond to see the mysteries of life and to find Reality and the Almighty. He believed Nature to be the best teacher and opined that every parcel of nature is a sign of God. He came to know about the holy scriptures of the East, especially those of the Indians and strongly used them in his writings, especially in Walden and the Week. Therefore such a person who seeks God, indeed, can be familiar with elements of humanism and Sufism, and one can find such elements in Walden by pondering its text.
\end{abstract}

Sufism simply means a love affair with the Almighty and the Ultimate. Sufism means the finding of God by an "inner-light" and by "contemplation" or "meditation" (fikr). Sufism knows no formality, so everyone can be a Sufi, whether a Christian, Moslem, Buddhist, or Jew. It is a relationship with God and actually is a dangerous relationship because the closer you come to God the more you evaporate. It is suicidal, but this suicide is so beautiful because to die in God is the only way to really live.

According to the sort of value attached to the fundamental principles chosen as the basis of organisation, "Sufism is spiritualism against materialism. As an ascetic philosophy, Sufism guarantees redemption from miseries of life, the knowledge as redeemer is identified with God. Thus according to Sufism, the supreme Truth or Reality is God" (Sharda, 1998, p. 23). Since God as Pure Being is the object of realisation in Sufism, and further is above thought and knowledge, a certain mystic condition of ecstasy became the means and sign of unity with Him. Its philosophy, as a theory of the means of attaining this mystic unity, tends to become theosophy. 
Osho also claims "Sufism is a vision - a love vision, a loving approach toward reality. It is falling in love with existence. Existence is waiting for you to come close so that it can reveal its heart. Existence is waiting for you to fall in love with it. If you are deeply in love with existence, it starts opening, it starts revealing its secrets. It has been waiting long for you to come close. Sufism is a world, but not a world-view. It is transcendence, but not a philosophy of transcendence. It does not preach any theories; it simply gives you practical hints. Sufism is not speculative. It is utterly realistic, pragmatic, and practical, it is down-to-earth, and it is not abstract". Sufism is the mystical dimension of Islam based on the esoteric, or "inner-meaning" of its scripture, namely the Koran. Sufism's central doctrine is based on a verse of the Koran, in which God says, "I created man and breathed My spirit into him." This "Divine spark" placed into every individual, says the Sufi must be nurtured and cherished.

Therefore, Sufism contains all wholesome and good deeds and it is clear that one who follows Only God really can be the best, or a Sufi as Mansour Hellaj.

Let us start our look at these elements in Thoreau with the best and most remarkable one -

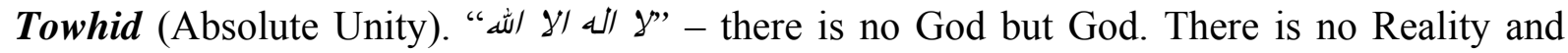
Clear Target rather than God and actually this world is only an illusion, and finally all of us shall return to Him.

The lost child always seeks his/her mother impatiently and until they find her they cannot enjoy, sleep, eat well, and get rid of thoughts. As the same child all of us have lost our Origin and we are always searching for it. A man of God, Thoreau, one night while he was a young boy, found it difficult to sleep at night and when his mother enquired of him why he could not sleep, he replied: "Mother, I have been looking through the stars to see if I could see God behind them" (Deshmukh, 1974, p. 3).

Thoreau stayed for more than two years far from society in the woods and it was a great opportunity for him to get experiences of the mysterious life. He found the hidden realities of Nature and God in every parcel of Nature. It would be no exaggeration to say that for the most part Thoreau's life was dominated and determined by the Walden sprite.

Walden envisages all his findings through Nature and it is not incredible to observe so many mystical and Sufi elements in this salient work of art. Therefore, some eminent elements of Sufism in this study from Walden are cited.

The outcome of the Walden experiment is chiefly to be sought in its reiteration of faith in the individual. In the final, and also the initial, analysis it is the individual that matters and notwithstanding great political movement, social change and mass upheavals the strings are pulled by a single individual and the mass or the mob goes up or down along with the overtowering individual. In Walden, towards the close, we have this somewhat prophetic utterance, "this said that the British Empire is very large and respectable and that the United States are a first rate power. We don't believe that a tide rises and falls behind every man, which can float the British Empire like a chip, if he should ever harbor it in his mind" (Deshmukh, 1974, pp. 29-30). Walden is the record of an experience in serene living, a venture in simplicity and discipline as timely today as it was nearly 100 years ago. In Walden, Thoreau found that poverty is not poverty ( Mayer, 1977, p. 54).

He states about his stay in Walden:

"I went to the woods because I wished to live deliberately, to front only the essential facts of life and see if I could not learn what it had to teach and not, when I came to die, discover that 
I have not lived........... I wanted to live deep and suck out all the marrow of life, to live so Spartan-like as to put to rout all that was not life, to cut a broad swath shave close, to life into a corner and reduce it to its lowest terms, and if it proved to be mean, why then to get the whole and genuine meanness of it and publish its meanness to the world; or if it were sublime to know it by experience and be able to give a true account of it in my next excursion... I learned this at least by my experiment that if one advances confidently in the direction of his dreams and endeavors to live the life he has imagined he will meet with a success unexpected in common hours" (Deshmukh, 1974, p. 29). Solitude or individuality is one of the elements of Sufism and Thoreau follows that as well as Sufis and there is no policy behind it rather than finding of God.

Longing for solitude is not due to any misanthropy or hatred of company but for self-relation, for coming to grips with oneself and thus emerging from every dose of solitude a whit stronger to face and to live one's life. It is thus that a man discovers the best in himself (selfknowing) and lives a fuller and a richer life (Deshmukh, 1974, p. 26), as Imam Ali also has mentioned (من اعرف نفسه فقد اعرف ريه).

Thoreau's communion with nature in Walden was one of the requirements of his philosophical needs. It was a part of his self-exploration, for he wanted to discover his own self indirectly through nature. So while at Walden, Thoreau merged with nature and, through nature, with God. He felt that he was an essential part of nature.

Thoreau's quest for individuality was not political in its motivation. It was primarily moral and spiritual. For Thoreau, the individual soul is the very embodiment of godhood - nay God itself and the body was the temple which we erect for him. Purity thus was the essential per-condition of living. A life devoid of purity, by its very nature, demands chastity and restraint and moderation not only in matters of sex, however the body craves for it (Deshmukh, 1974, p. 30).

There is no doubt Thoreau was influenced by Indian philosophy also and he traces so much of Hinduism in his works, especially Walden.

According to Deshmukh, "Certainly there is no doubt that Walden is permeated with a vaguely Hindu atmosphere. There are many overt references to the sacred texts of India..... And Thoreau himself follows certain Hindu customs... There are also many less obvious references, for example, to the language of silence which is so common in India and which is invoked in Thoreau's silent communion with the old fisherman who joined him at the pond. Flute-playing, his own and that of John Farmer, is also reminiscent of the god Krishna's favorite musical pastime. Most significant of all are many references to the river and the definite equation of the Walden Pond with the sacred Ganges. To dismiss all of these references as simply part of Thoreau's temperamental affinity to India is to underestimate the extraordinary influence of the orient on his thinking and to misunderstand the purpose of Walden" (Deshmukh, 1974, pp.72-73). "In comparison with the philosophers of the east we may say that modern Europe has yet given birth to none. Beside the vast and cosmogonal of the Bhagvad Gita even our Shakespeare seems sometimes youthfully green and practical merely" (Deshmukh, 1974, p. 43).

Speaking about the simplicity and universality of the Vedas, Thoreau says "what extracts from the Vedas I have read fall on me like the light of a higher and purer luminary which describes a loftier course through a purer stratum free from a particular simple universal. I rise 
on me like the full moon after the stars have come out wading through some far summer stratum of the sky" (Deshmukh, 1974, p. 44).

The simplicity and other writings provide ample proof of his admiration for it, as also the way he led his life. Talking of Hindu Sufi's austerity he says "the very austerity of these Hindus in tempting to the devotionals as a more refined and nobler luxury... one may discover the root of a Hindu religion in his own private history when in the silent intervals of the day or the night he dose sometimes inflict on himself like austerities with a stern satisfaction (reza)" (Deshmukh, 1974, p. 44).

The concept of Maya (illusion) is another important contribution that Indian sages and Sufis make to world philosophy. According to it the whole of creation is an illusion, a sort of dream, and our lives here are only momentary and dreamlike. We ultimately return to Brahma, the absolute reality (God in Sufism). In our utter ignorance we regard the unreal as real and are unmindful of the Eternal Reality. But Maya being the creative potent is essential because without Maya there would be no creation, Brahma being immutable, indifferent and peacefully inactive.

The theme of the renunciation (fana), which in certain ways is central to the teachings of Sufism and has been advocated in almost all the scriptures, finds expression in Thoreau's writings in a number of places. The Walden experiment itself was renunciation put into action. Thoreau's persistent refusal to get involved in the affairs of the world is proof only of his conviction of this creed. Even his idea of simplicity is only an approximation of the concept of renunciation. Let our affairs be of two and three and not of a hundred and thousand, he says. Our wants, if they cannot be completely done away with, are to be brought to a minimum. Our food, dress and furniture are all to be ruthlessly simplified. The whole world and its affairs are to be regarded as of no consequence. His utter disregard of what are known practical considerations is voiced in this: "what after all, does the practicalness of life amount to? These things immediate to be done are very trivial. I could postpone them all to hear this locust sing. The most glorious fact in my experience is not anything that $\mathrm{I}$ have done or may hope to do, but a transient thought or vision, or dream which I have had. I would give all the wealth of the world, and all the deeds of all the heroes, for one true vision" (Deshmukh, 1974, p. 65).

C.R Anderson, in his profound study of Walden entitled The Magic Circle of Walden, has very freely and frankly admitted the Hindu atmosphere of the book; apart from the fact that one of the chapters, incidentally, is entitled Maya, the entire book is interspersed with sentences like these: "Thoreau found in the Orientals what neither neo-Platonists nor Christians could give him. He was more deeply read in the oriental scriptures than any of the other transcendentalists." The Oriental Bibles proved his best source for imagery of the spiritual life (Deshmukh, 1974, p. 73).

Henry Seidel Canby's excellent biography "Thoreau - the biography of a man who believed in doing what he wanted" (1939) shows a much better appreciation of the situation when he says, "but the Bhagvad Gita was explicit and like Emerson's Nature, went deep down into his consciousness and gave him a new birth" (Deshmukh, 1974, p. 77).

Most of the luxuries, and many of the so-called comforts of life, are not only not dispensable, but positive hindrances to the elevation of mankind. With respect to luxuries and comforts, the wise have always lived a more simple and merged life than the poor. The ancient 
philosophers, Chinese, Hindu, Persian, and Greek, were a class of which none has been poorer in outward riches, but none so rich inwardly (Tripathy, 1992, pp. 67-68).

Thoreau's real purpose at Walden Pond as well as throughout his whole life was to educate the whole of mankind to realise the divine in man.

"Visitors" and "the Bean Field", two chapters of Walden, show the clear impact of the Laws of Manu; the Laws emphasise to a great extent the need for solitude. It gives directive to the Brahmin to practise solitude: "Alone in some solitary place, let him constantly meditate on the divine nature of the soul, for by such meditation he will attain happiness" (Tripathy, 1992, p.75).

Thoreau's task, then, would seem to be to teach mankind enough science so that they could, in the end, move beyond science into that condition of Transcendental elevation of sainthood which is his great goal and the particular focus of his greatest work, Walden (Hildebidle, 1983, p. 97).

Walden begins with a discussion of the means utilised, and concludes with an invitation to all to wake up, explore themselves, and find out who they are. The constant theme in Walden is that of "spiritual" awakening. It appears in metaphor in almost every chapter, the commonest symbols being those of spring, morning, and restorative medicines. It is reflected in the overall structure of the book. Although Thoreau lived at Walden Pond for more than two years, his book is an ideal account as a single year, following the seasons from summer to spring. The seasonal change from winter to spring is exploited metaphorically at the end to describe the awakening of the human being to self-realisation, well-being, and development. It is time, he means, for the whole human race to awaken, and assume a consciousness it has rarely shown yet, and seize its opportunity to live.

Although Thoreau's vocabulary still retains the words "soul", "divine", and "spiritual" they must be understood in quotation marks. In the chapter "Higher Laws" he refers to the "higher, or, as it is named, spiritual life ..." (Sherman, 1972, p. 72); in a later letter, a few years after the publication of Walden, he says, "our souls (I use this word for want of a better) ..." (Sherman, 1972, p. 72). There are at least two suggestions as to what he may mean by "Higher Laws". First, that natural law supports the development of the spiritual man: "...the laws of the universe are not indifferent, but are forever on the side of the most sensitive. Listen to every zephyr for some reproof, for it is surely there, and he is unfortunate who does not hear it" (W, II, 242). Or second, that "Laws" mean self-regulations according to the moral principles that rise from the "suggestions of his genius," (W, II, 239) which man must respect. In the Holy Koran one can constantly find verses about the ignorance of men while they are observing the various signs of God in Nature, which are the eminent teachers for the students of Nature.

It is important that Thoreau emphasises man's ignorance, and the difficulty with which he wrests from nature "truths" that will satisfy his craving for reality. The idealist invariably assumes an a priori known structure. Thoreau adheres to the empirical approach and in Walden he writes: "If we knew all the laws of Nature, we should need only one fact, or the description of one actual phenomenon, to infer all the results at that point. Now we know only a few laws, and our result is vitiated, not, of course, by any confusion or irregularity in Nature, but by our ignorance of essential elements in the calculation" (Sherman, 1972, p. 80). 
Consequently, Thoreau's real purpose at Walden Pond as well as throughout his whole life was to educate the whole of mankind to realise the divine in man as Emerson also claimed "God in man but incomplete".

\section{Works cited:}

Deshmukh, D. G. 1974. Thoreau and Indian Thought. Nagpur: Nagpur University Press.

Mayer, M. 1977. Several more Lives to Live. Conneticut: Greenwood Press.

Hildebidle, J. 1983. Thoreau: A Naturalists Liberty. Cambridge: Harvard University Press.

Sharda. S. R. 1998. Sufi Thought: Its development in Panjab and its impact on Panjabi literature from Baba Farid to AD 1850. New Delhi: Munshiram Mannoharal Publishers Pvt.Ltd.

Sherman, P. (ed). 1962. Thoreau: A Collection of Critical Essays. New Jersey: Prentice-Hall, Englewood Cliffs.

Tripathy, S. 1992. Henry David Thoreau: Quest for Hindu Idealism. Bhubaneswar: Kalinga Printers.

\section{Ali Arian}

Azerbaijan Shahid Madani University

Tabriz

Iran

ali_arian2005@yahoo.com 